\title{
Protein and energy relations in the broiler chicken
}

\author{
8. Comparison involving protein- and lysine-adequate and inadequate \\ diets on lipid metabolism
}

\author{
BY R. W. ROSEBROUGH, A. D. MITCHELL, M. F. VON VLECK \\ AND N.C.STEELE \\ Non-ruminant Animal Nutrition Laboratory, Livestock and Poultry Sciences Institute, United States \\ Department of Agriculture-Agricultural Research Service, Beltsville Agricultural Research Center, \\ Beltsville, MD 20705, USA
}

(Received 26 May 1989 - Accepted 11 May 1990)

\begin{abstract}
Chickens were fed on diets containing either $12.8 \mathrm{MJ}, 150 \mathrm{~g}$ crude protein (nitrogen $\times 6.25$ ) $/ \mathrm{kg}$ or $12.8 \mathrm{MJ}, 200 \mathrm{~g}$ crude protein $/ \mathrm{kg}$ to determine differences in metabolism. The diet containing $12.8 \mathrm{MJ}$, $150 \mathrm{~g}$ crude protein $/ \mathrm{kg}$ contained either 8 or $12 \mathrm{~g}$ lysine $/ \mathrm{kg}$. Treatment variables examined in vitro were lipogenesis, glucose production and hepatic enzyme activities to compare metabolism in chicks fed on a low-protein, lysine-supplemented diet and a diet formulated to contain the required amount of lysine from intact protein. Growth was similar in chicks fed on diets containing either $12.8 \mathrm{MJ}, 154 \mathrm{~g}$ crude protein with $12 \mathrm{~g}$ lysine $/ \mathrm{kg}$ or $12.8 \mathrm{MJ}, 200 \mathrm{~g}$ crude protein $/ \mathrm{kg}$. Net glucose production was greater $(P<0.05)$ in liver explants from chickens fed on diets containing either $12.8 \mathrm{MJ}, 154 \mathrm{~g}$ crude protein with $12 \mathrm{~g}$ lysine $/ \mathrm{kg}$ or $12.8 \mathrm{MJ}, 200 \mathrm{~g}$ crude protein $/ \mathrm{kg}$ than in explants from chickens fed on $12.8 \mathrm{MJ}, 150 \mathrm{~g}$ crude protein with $8 \mathrm{~g}$ lysine/kg. Pyruvate use for glucose production was greater $(P<0.05)$ in chickens fed on a diet containing $12.8 \mathrm{MJ}, 150 \mathrm{~g}$ crude protein with $8 \mathrm{~g}$ lysine $/ \mathrm{kg}$. The findings from the present study suggest that crystalline and 'natural' lysine additions to chick diets may influence metabolism differently.
\end{abstract}

\section{Lysine:Protein:Lipogenesis: Chicken}

Diets containing large energy: protein ratios ( $>72 \mathrm{MJ} / \mathrm{kg}$ crude protein (nitrogen $\times 6.25)$ ) promote high rates of in vitro lipogenesis (Rosebrough \& Steele, 1985a) as well as de novo carcass lipid synthesis by the liver of chickens (Donaldson, 1985). Diets with small energy: protein ratios ( $<56 \mathrm{MJ} / \mathrm{kg}$ crude protein) promote lean broiler carcasses (Donaldson et al. 1956; Thomas \& Combs, 1967). We have recently examined energy: protein ratios and have found different possible interpretations of results (Rosebrough \& Steele, 1985a). For example, giving a very small energy: protein diet ( $43 \mathrm{MJ} / \mathrm{kg}$ crude protein) will result in a very lean carcass (crude protein as a proportion of dry matter) when compared with results obtained by giving a larger energy:protein diet $(65 \mathrm{MJ} / \mathrm{kg}$ crude protein). When the findings were analysed on the basis of $g \mathrm{~N}$ deposited over the course of the experiment, it became obvious to us that the diet containing a larger energy: protein ratio favoured the deposition of more carcass protein as well as lipid. Thus, diets containing very small energy:protein ratios may promote lean carcasses by naturally restricting feed intake. Bartov (1979) has also proposed that the excretion of excess amino acid- $\mathrm{N}$ would require energy.

Both the quantity (crude protein concentration) and quality (amino acid composition relative to the required balance) of the dietary protein affect the body composition of chicks. If lysine is the limiting amino acid the effective protein level can be calculated according to the lysine content relative to the crude protein level. It was assumed that a completely effective protein contained $60 \mathrm{~g}$ lysine $/ \mathrm{kg}$ protein. Although the crude protein 
R. W. ROSEBROUGH AND OTHERS

Table 1. Composition of the diets $(\mathrm{g} / \mathrm{kg})$

\begin{tabular}{|c|c|c|c|}
\hline & \multicolumn{3}{|c|}{ Dietary crude protein (nitrogen $\times 6.25)(\mathrm{g} / \mathrm{kg})$} \\
\hline & 150 & 154 & 200 \\
\hline \multicolumn{4}{|l|}{ Ingredjent } \\
\hline Soya-bean protein* & & & 120 \\
\hline Soya-bean meal & 166 & 166 & 55 \\
\hline Maize meal & 727 & 727 & 727 \\
\hline Maize oil & 20 & 15 & \\
\hline Sand & 27 & 22 & 33 \\
\hline L-Lysine hydrochloridet & & 5 & \\
\hline L-Methionine & 5 & 5 & 5 \\
\hline Dicalcium phosphate & 40 & 40 & 40 \\
\hline Limestone & 10 & 10 & 10 \\
\hline Selenium premix§ & 1 & 1 & 1 \\
\hline Mineral premix & 1 & 1 & 1 \\
\hline Vitamin premix & 5 & 5 & 5 \\
\hline Iodized salt & 3 & 3 & 3 \\
\hline \multicolumn{4}{|l|}{ Calculated composition } \\
\hline Metabolizable energy (MJ) & $12 \cdot 9$ & $12 \cdot 8$ & $12 \cdot 9$ \\
\hline Lysine $(\mathrm{g} / \mathrm{kg})$ & $8 \cdot 1$ & $12 \cdot 1$ & $12 \cdot 3$ \\
\hline Sulphur-amino acids $(\mathrm{g} / \mathrm{kg})$ & $9 \cdot 9$ & $9 \cdot 9$ & $9 \cdot 9$ \\
\hline
\end{tabular}

* Soya-bean protein grade II (21726); US Biochemicals, PO Box 22400, Cleveland, Ohio 44122.

$\dagger$ L-Lysine hydrochloride (18585); US Biochemicals.

$\ddagger$ L-Methionine (18915); US Biochemicals.

$\S$ Provided $0.2 \mathrm{mg} \mathrm{Se} / \mathrm{kg}$ diet.

|| Provided (mg/kg diet): manganese 100, iron 100, copper 10, cobalt 1, iodine 1, zinc 100, calcium 89 .

I Provided (mg/ $\mathrm{kg}$ diet): retinol 3.6, cholecalciferol 0.075, biotin 1, vitamin E 10, riboflavin 10, pantothenic acid 20, choline $2 \mathrm{~g}$, niacin 100 , thiamin 10 , vitamin $\mathbf{B}_{6} 10$, menadione sodium bisulphite $1 \cdot 5$, cyanocobalamin $0 \cdot 1$, folic acid 2, ethoxyquin 150 .

level $(\mathrm{g} / \mathrm{kg}$ diet), as well as the effective dietary protein level (percentage of the requirement of the first limiting amino acid present in the diet), may regulate lipogenesis, it is unknown if the effect is due to the presence of a limiting amino acid at the ribosomal level or to a shift in cellular metabolism caused by a need to process excess amino acid-carbon. In addition, in the process of converting gluconeogenic amino acid-C into glucose- $\mathrm{C}$, reducing equivalents (NADH, NADPH) normally required for the addition of acetyl residues during de novo lipogenesis are utilized and may be unavailable for lipogenesis (Yeh \& Leveille, 1969).

The purpose of the experiments described in the present report was to examine lipid and carbohydrate metabolism in chickens fed on additional amounts of the limiting amino acid lysine as either lysine hydrochloride or soya-bean meal. The null hypothesis tested was that lysine supplementation of a low-protein diet would influence metabolism similarly to a diet containing a greater amount of crude protein. In the former case, the effective protein level (g lysine $/ \mathrm{kg}$ crude protein) would increase and in the latter case, the effective level would remain at $60 \mathrm{~g}$ lysine $/ \mathrm{kg}$ crude protein. A maize-soya-bean meal basal diet was formulated to be marginally adequate for all essential amino acids with the exception of lysine. Crystalline lysine hydrochloride was then added to give a total of $12 \mathrm{~g} / \mathrm{kg}$ diet.

\section{EXPERIMENTAL PROCEDURES}

\section{Animals}

Ross male broiler chicks (7-d-old) were assigned to one of three dietary treatments ( $150 \mathrm{~g}$ crude protein with $8 \mathrm{~g}$ lysine, $154 \mathrm{~g}$ crude protein with $12 \mathrm{~g}$ lysine and $200 \mathrm{~g}$ crude protein 
with $12 \mathrm{~g}$ lysine $/ \mathrm{kg}$ diet). The latter diet which depended on meeting the lysine requirement $(12 \mathrm{~g} / \mathrm{kg}$ diet and $60 \mathrm{~g}$ lysine $/ \mathrm{kg}$ crude protein) for the 7- to 28 -d-old chicken (National Research Council, 1984) was used as a control diet. The diets are described in Table 1. Chickens were housed in heated battery brooders in a light-and temperature-controlled room maintained at $22^{\circ}$ with $24 \mathrm{~h}$ of light. Each battery was considered a block and treatments were randomly assigned to pens in each battery. There were a total of four replicate pens containing eight chickens for each dietary treatment. For purposes of statistical analyses, the observation was the pen mean.

\section{In vitro metabolic studies}

Two 28-d-old chickens were randomly selected from each pen replicate treatment and killed by cervical dislocation at 09.00 hours. The livers were rapidly excised, weighed and placed in individual vessels containing $10 \mathrm{~mm}$-HEPES $(N$-2-hydroxyethyl piperazine- $N$ '-2-ethane sulphonic acid) and $155 \mathrm{~mm}$-sodium chloride ( $\mathrm{pH} \mathrm{7.5).} \mathrm{A} \mathrm{portion} \mathrm{of} \mathrm{the} \mathrm{liver} \mathrm{was} \mathrm{sliced} \mathrm{with}$ a Stadie-Riggs hand microtome (50-75 mg/explant) and duplicate explants were incubated for $2 \mathrm{~h}$ at $37^{\circ}$ in $25-\mathrm{ml}$ Erlenmeyer flasks containing $3 \mathrm{ml}$ Hanks' balanced salts (Hanks \& Wallace, 1949) supplemented with 20 mM-HEPES ( $\mathrm{pH} \mathrm{7.4)}$ and $10 \mathrm{~g}$ bovine serum albumin/l. Under the described assay conditions, we have found that reactions are linear from 1 to $4 \mathrm{~h}$ with substrate concentrations from 5 to $40 \mathrm{~mm}$ (Rosebrough \& Steele, 1987). Explants were incubated in the presence of $20 \mathrm{~mm}-\left[2-{ }^{14} \mathrm{C}\right]$ pyruvate (37 disintegrations $/ \mathrm{min}$ per nmol), $20 \mathrm{~mm}-\left[3-{ }^{14} \mathrm{C}\right]$ pyruvate $\left(37\right.$ disintegrations/min per $\mathrm{nmol}$ ) or $20 \mathrm{~mm}-\left[2-{ }^{14} \mathrm{C}\right]$ sodium acetate ( 37 disintegrations/min per nmol). Following a $2 \mathrm{~h}$ incubation period, $0.1 \mathrm{ml} 5 \mathrm{~m}$-potassium hydroxide was injected onto filter papers lining wells suspended in each of the flasks to trap carbon dioxide, and $0.3 \mathrm{ml} 2 \mathrm{M}$-sulphuric acid was injected into the media to stop metabolic processes and liberate $\mathrm{CO}_{2}$ produced during the incubation. The incubation was continued for an additional $1 \mathrm{~h}$ to ensure adequate $\mathrm{CO}_{2}$ trapping. The liver explants were extracted for $24 \mathrm{~h}$ in $15 \mathrm{ml}$ chloroform-methanol $(2: 1, \mathrm{v} / \mathrm{v})$ and fractionated with $3 \mathrm{ml} 155 \mathrm{~mm}$-potassium chloride (Folch et al. 1957). The lower phase was then evaporated to dryness and saponified with $2 \mathrm{M}$-methanolic $\mathrm{KOH}$. The non-saponified fraction was removed with two $10 \mathrm{ml}$ hexane washes and the fatty acids were removed into $10 \mathrm{ml}$ hexane following acidification with $6 \mathrm{M}$-hydrochloric acid and evaporated to dryness. This fraction was then dispersed in Scintiverse ${ }^{\mathbb{B}}$ (Fisher Scientific, Pittsburgh, PA, USA) and counted with a liquid-scintillation counter. Product radioactivity was then divided by the specific activity of the respective radiolabelled precursor to establish the quantity of precursor utilized. Activity was noted as the quantity of labelled acetate or pyruvate used in the incubation and recovered as $\mathrm{CO}_{2}$ or fatty acids. This value was then expressed as $\mu \mathrm{mol} / \mathrm{kg}$ body-weight on the basis of relative liver size of the chicken. This calculation was obtained by using the following formula: $\mu \mathrm{mol} / \mathrm{g}$ liver $\times$ total liver weight $\div$ bodyweight $\times 1000$.

A $1 \mathrm{ml}$ portion of the $3 \mathrm{ml}$ incubation volume containing either $20 \mathrm{~mm}-\left[2-{ }^{14} \mathrm{C}\right]$ pyruvate or $20 \mathrm{~mm}-\left[3-{ }^{14} \mathrm{C}\right]$ pyruvate was applied to a $7 \times 30 \mathrm{~mm}$ column containing AG $1-\mathrm{X} 8$, $\mathrm{HCOO}^{-}$(Yeh \& Leveille, 1969). Glucose was eluted with $5 \mathrm{ml}$ water and measured with glucose oxidase (EC 1.1.3.4)-peroxidase (EC 1.11.1.7). Radioactivity in the fraction containing glucose was also determined. The specific activity of glucose was then divided by the specific activity of the respective precursor to derive the mass of product formed. Net glucose production was determined by measuring glucose in samples of medium following the incubation. The difference attributed to pyruvate was noted as net glucose production.

Remaining liver tissue was homogenized $(1: 10, \mathrm{w} / \mathrm{v})$ in $100 \mathrm{~mm}-\mathrm{HEPES}(\mathrm{pH} 7 \cdot 5)-3 \cdot 3$ mM-mercaptoethanol and centrifuged at $50000 \times g$ for $60 \mathrm{~min}$. The supernatant fractions were kept at $0^{\circ}$ until analysed for malic enzyme $(E C$ 1.1.1.40; $\mathrm{ME})$, isocitrate dehydro- 
genase (NADP) ( $E C$ 1.1.1.42; ICD) and aspartate aminotransferase (EC 2.6.1.1; ASPT). ME activity was determined by a modification of the method of Hsu \& Lardy (1969). The reaction contained $50 \mathrm{~mm}$-HEPES (pH 7.5), 1 mM-NADP, 5 mm-manganese chloride and the substrate, $2.2 \mathrm{~mm}-\mathrm{L}-$ malate (disodium salt). A $50 \mu \mathrm{l}$ portion of the $50000 \times g$ supernatant fraction was pre-incubated for $15 \mathrm{~min}$ in the presence of the first three ingredients. The reaction was initiated by adding the substrate and following the rate of reduction of NADP at $340 \mathrm{~nm}$ at $25^{\circ}$. The reaction was found to proceed in a linear manner for at least $60 \mathrm{~min}$ providing that the reaction contained nor more than $100 \mu \mathrm{g}$ supernatant protein.

ICD was determined by a modification of the method of Cleland et al. (1969). The reaction contained $50 \mathrm{~mm}-\mathrm{HEPES}$ ( $\mathrm{pH} 7 \cdot 5$ ), $1 \mathrm{~mm}$-NADP, $5 \mathrm{~mm}-\mathrm{MnCl}_{2}$ and the substrate, $4.4 \mathrm{~mm}$-DL-isocitrate. A $25 \mu \mathrm{l}$ portion of the $50000 \times \mathrm{g}$ supernatant fraction was preincubated for $15 \mathrm{~min}$ in the presence of the first three ingredients. The reaction was initiated by adding the substrate and following the rate of reduction of NADP at $340 \mathrm{~nm}$ at $25^{\circ}$. The reaction was found to proceed in a linear manner for at least $60 \mathrm{~min}$ providing that the reaction contained no more than $50 \mu \mathrm{g}$ supernatant protein. ASPT was determined by a modification of the method of Martin \& Herbein (1976). The reaction contained $50 \mathrm{~mm}-$ HEPES, $200 \mathrm{~mm}$-L-aspartate, $0.2 \mathrm{~mm}-\mathrm{NADH}, 1000$ units malic dehydrogenase ( $E C$ 1.1.1.37)/1 and the substrate, $15 \mathrm{~mm}$-2-oxoglutarate. A $25 \mu$ l portion of the $50000 \times \mathrm{g}$ supernatant fraction was pre-incubated for $15 \mathrm{~min}$ in the presence of the first four ingredients. The reaction was initiated by adding the substrate and following the rate of oxidation of NADH at $340 \mathrm{~nm}$ at $25^{\circ}$. The reaction was found to proceed in a linear manner for at least 30 min providing that the reaction contained no more than $50 \mu \mathrm{g}$ supernatant protein. Activities of all enzymes are expressed as $\mu \mathrm{mol}$ product formed $/ \mathrm{min}$ under the assay conditions (Rosebrough \& Steele, 1985a).

Data were analysed as a randomized block design. The model included dietary treatments randomized within blocks (batteries). Significance of pairwise comparisons was determined with a Student's $t$ test (Kirk, 1968).

\section{RESULTS}

Body-weights and feed consumption are presented in Table 2 . Chickens fed on the diet containing $150 \mathrm{~g}$ crude protein and $8 \mathrm{~g}$ lysine $/ \mathrm{kg}$ were lighter $(P<0.05)$ than chickens fed on the diet containing either $154 \mathrm{~g}$ crude protein and $12 \mathrm{~g}$ lysine $/ \mathrm{kg}$ or $200 \mathrm{~g}$ crude protein and $12 \mathrm{~g}$ lysine $/ \mathrm{kg}$. Feeding the latter two diets resulted in chickens nearly equal in weight. Efficiencies of food utilization were similar among all treatment groups.

The relative rates of net glucose production as well as the utilization of pyruvate for glucose production in vitro are presented in Table 3 . An increase in dietary lysine (154 $\mathrm{g}$ crude protein with $12 \mathrm{~g}$ lysine $/ \mathrm{kg}$ diet) and crude protein status ( $200 \mathrm{~g}$ crude protein $/ \mathrm{kg}$ diet $)$ increased $(P<0.05)$ net glucose production compared with feeding a diet containing $150 \mathrm{~g}$ crude protein and $8 \mathrm{~g}$ lysine $/ \mathrm{kg}$. An examination of the use of pyruvate by liver explants from chickens consuming these diets revealed that, in contrast to pyruvatedependent glucose production noted previously, the use of pyruvate as a glucose precursor was greater $(P<0.05)$ in liver explants from chickens receiving the diet containing $200 \mathrm{~g}$ crude protein $/ \mathrm{kg}$ than for either of the other treatments. A calculation of the ratios for utilization of $\left[2-{ }^{14} \mathrm{C}\right]$ and $\left[3-{ }^{14} \mathrm{C}\right]$ pyruvate showed that both label positions appeared in glucose. A comparison of rates of utilization showed that $\left[3-{ }^{14} \mathrm{C}\right]$ pyruvate appearance exceeded that for $\left[2-{ }^{14} \mathrm{C}\right]$ pyruvate in chicks given the required amount of dietary lysine whether from additional soya-bean meal or from lysine hydrochloride.

A comparison of relative rates of substrate usage showed that pyruvate utilization exceeded $(P<0.05)$ that for acetate as both a lipogenic (Table 4$)$ and oxidative substrate 
Table 2. Dietary crude protein (nitrogen $\times 6 \cdot 25$ ) level, lysine supplementation and chick growth*

(Mean values are average individual bird weights for pens treated alike)

\begin{tabular}{|c|c|c|c|c|}
\hline \multirow[b]{2}{*}{$\begin{array}{l}\text { Crude protein } \\
(\mathrm{g})\end{array}$} & \multirow[b]{2}{*}{$\begin{array}{l}\text { Lysine content } \\
\text { (g) }\end{array}$} & \multirow[b]{2}{*}{$\begin{array}{c}28 \mathrm{~d} \text { body-wt } \\
\text { (g) }\end{array}$} & \multicolumn{2}{|c|}{ 7-28 d performance } \\
\hline & & & $\begin{array}{l}\text { Wi gain } \\
(\mathrm{g})\end{array}$ & $\begin{array}{c}\text { Food eaten } \\
\text { (g) }\end{array}$ \\
\hline 150 & 8 & 872 & $727^{a}$ & $1112^{\mathrm{a}}$ \\
\hline 154 & 12 & 945 & $800^{\mathrm{b}}$ & $1280^{\mathrm{b}}$ \\
\hline 200 & 12 & 941 & $796^{b}$ & $1257^{\mathrm{b}}$ \\
\hline Pooled SEM & & & 20 & 43 \\
\hline
\end{tabular}

a.b Values within a column with unlike superscript letters were significantly different $(P<0 \cdot 05)$

* Chickens (7-d-old; average of $145 \mathrm{~g}$ ) were assigned to these dietary treatments: (I) control, $200 \mathrm{~g}$ crude protein and $12 \mathrm{~g}$ lysine $/ \mathrm{kg}$ diet, (2) $150 \mathrm{~g}$ crude protein and $8 \mathrm{~g}$ lysine $/ \mathrm{kg}$ diet or (3) $154 \mathrm{~g}$ crude protein and $12 \mathrm{~g}$ lysine $/ \mathrm{kg}$ diet for a $21 \mathrm{~d}$ experimental period. Chickens were then selected from each treatment to determine the effects of dietary treatments on intermediary metabolism.

Table 3. Effect of dietary crude protein (nitrogen $\times 6 \cdot 25)$ level and lysine supplementation on the use of pyruvate as a substrate for in vitro glucose metabolism (incorporation of $\left[2{ }^{14} \mathrm{C}\right]-$ and $\left[3-{ }^{14}\right.$ C]pyruvate into media glucose and total media glucose change) by liver explants from broiler chickens*

(Mean values for four pen means per dietary treatment are expressed as $\mu$ mol substrate utilized $/ \mathrm{kg} \mathrm{body-}$ weight)

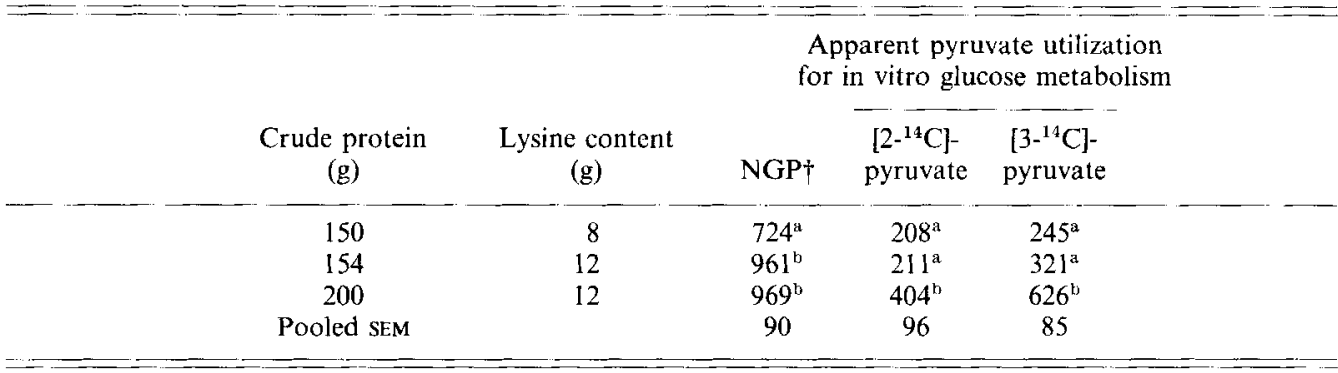

NGP, net glucose production.

a,b Values within a column with unlike superscript letters were significantly different $(P<0.05)$.

* Chickens (7-d-old; average of $145 \mathrm{~g}$ ) were assigned to these dietary treatments: (1) control, $200 \mathrm{~g}$ protein and $12 \mathrm{~g}$ lysine $/ \mathrm{kg}$ diet, (2) $150 \mathrm{~g}$ protein and $8 \mathrm{~g}$ lysine $/ \mathrm{kg}$ diet or (3) $154 \mathrm{~g}$ protein and $12 \mathrm{~g}$ lysine $/ \mathrm{kg}$ diet for a $21 \mathrm{~d}$ experimental period. Chickens were then selected from each treatment to determine the effects of dietary treatments on intermediary metabolism.

† Calculated by incubating explants with or without $20 \mathrm{~mm}$-pyruvate and determining the change in media glucose. Values are expressed as $\mu \mathrm{mol}$ glucose produced $/ \mathrm{kg}$ body-weight.

(Table 5). An increase in crude protein decreased $(P<0.05)$ de novo fatty acid synthesis from both pyruvate and acetate. A slight, though significant $(P<0.05)$ decrease in pyruvate utilization for lipogenesis was noted when lysine hydrochloride was added to the lower-protein diet. In contrast to the apparent differences in pyruvate- $C$ appearing in glucose, both of the two labelled pyruvate-carbons appeared at the same rate in the lipid product, indicating a common pathway before incorporation into a final product.

Diets did not influence $\mathrm{CO}_{2}$ production although, at all protein levels, utilization of pyruvate surpassed $(P<0.05)$ that for acetate and indicated unequal competition between the two substrates for metabolic pathways. The $\left[2-{ }^{14} \mathrm{C}\right]$ pyruvate : $\left[3-{ }^{14} \mathrm{C}\right]$ pyruvate utilization 
Table 4. Effect of dietary crude protein (nitrogen $\times 6.25$ ) level and lysine supplementation on the use of either acetate or pyruvate as substrates for in vitro lipogenesis (incorporation of $\left[2-{ }^{14} \mathrm{C}\right]$ acetate, $\left[2-{ }^{14} \mathrm{C}\right]$ pyruvate and $\left[3-{ }^{14} \mathrm{C}\right]$ pyruvate into hepatic fatty acids) by liver explants from broiler chickens*

(Mean values for four pen means per dietary treatment are expressed as $\mu$ mol substrate utilized $/ \mathrm{kg}$ bodyweight)

\begin{tabular}{|c|c|c|c|c|}
\hline \multirow[b]{2}{*}{$\begin{array}{l}\text { Crude protein } \\
(\mathrm{g})\end{array}$} & \multirow[b]{2}{*}{$\begin{array}{l}\text { Lysine content } \\
\text { (g) }\end{array}$} & \multicolumn{3}{|c|}{$\begin{array}{c}\text { Apparent pyruvate and acetate } \\
\text { utilization } \\
\text { for in vitro lipogenesis }\end{array}$} \\
\hline & & $\begin{array}{l}{[2-14 \mathrm{C}]-} \\
\text { acetate }\end{array}$ & $\begin{array}{l}{\left[2-{ }^{14} \mathrm{C}\right]} \\
\text { pyruvate }\end{array}$ & $\begin{array}{l}{\left[3^{-14} \mathrm{C}\right]-} \\
\text { pyruvate }\end{array}$ \\
\hline 150 & 8 & $960^{\mathrm{b}}$ & $2431^{\mathrm{c}}$ & $2392^{c}$ \\
\hline 154 & 12 & $945^{b}$ & $2000^{\mathrm{b}}$ & $1880^{h}$ \\
\hline 200 & 12 & $448^{\mathrm{a}}$ & $1083^{a}$ & $1040^{a}$ \\
\hline Pooled SEM & & 116 & 119 & 121 \\
\hline
\end{tabular}

a.b.c Values within a column with unlike superscript letters were significantly different $(P<0 \cdot 05)$.

* Chickens (7-d-old; average of $145 \mathrm{~g}$ ) were assigned to these dietary treatments: (1) control, $200 \mathrm{~g}$ protein and $12 \mathrm{~g}$ lysine $/ \mathrm{kg}$ diet, (2) $150 \mathrm{~g}$ protein and $8 \mathrm{~g}$ lysine $/ \mathrm{kg}$ diet or (3) $154 \mathrm{~g}$ protein and $12 \mathrm{~g}$ lysine $/ \mathrm{kg}$ diet for a $21 \mathrm{~d}$ experimental period. Chickens were then selected from each treatment to determine the effects of dietary treatments on intermediary metabolism.

Table 5. Effect of dietary crude protein (nitrogen $\times 6 \cdot 25)$ level and lysine supplementation on the use of either acetate or pyruvate as substrates for in vitro oxidation (incorporation of $\left[2-{ }^{14} \mathrm{C}\right]$ acetate, $\left[2-{ }^{14} \mathrm{C}\right]$ pyruvate and $\left[3-{ }^{14} \mathrm{C}\right]$ pyruvate into $\left.\mathrm{CO}_{2}\right)$ by liver explants from broiler chickens*

(Mean values for four pen means per dietary treatment are expressed as $\mu$ mol substrate utilized $/ \mathrm{kg}$ bodyweight)

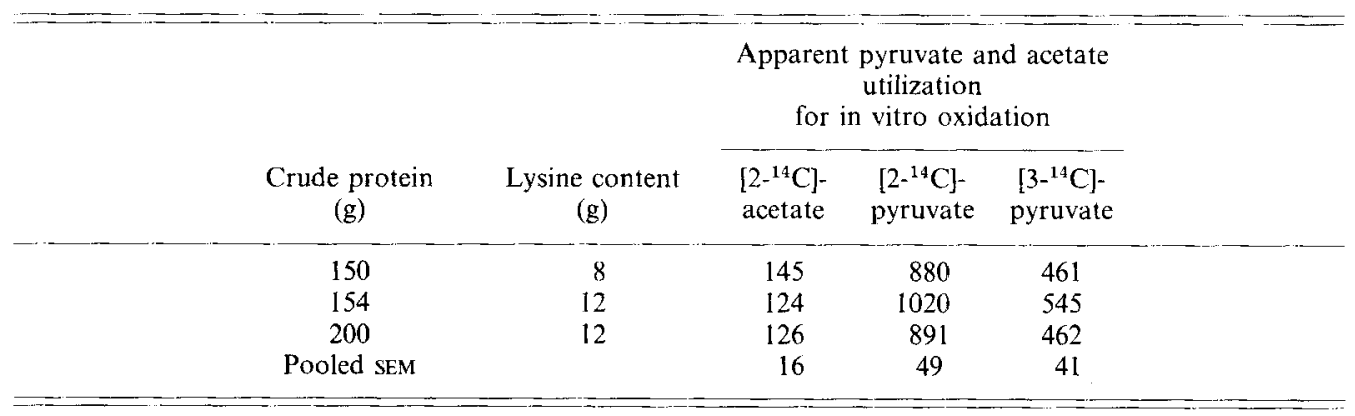

Values within a column were not significantly different $(P>0 \cdot 05)$.

* Chickens ( 7 -d-old; average of $145 \mathrm{~g}$ ) were assigned to these dietary treatments: (1) control, $200 \mathrm{~g}$ protein and $12 \mathrm{~g}$ lysine $/ \mathrm{kg}$ diet, (2) $150 \mathrm{~g}$ protein and $8 \mathrm{~g}$ lysine $/ \mathrm{kg}$ diet or (3) $154 \mathrm{~g}$ protein and $12 \mathrm{~g}$ lysine $/ \mathrm{kg}$ diet for a $21 \mathrm{~d}$ experimental period. Chickens were then selected from each treatment to determine the effects of dietary treatments on intermediary metabolism.

ratio for $\mathrm{CO}_{2}$ was similar for all dietary treatments; however, apparent utilization of [2$\left.{ }^{14} \mathrm{C}\right]$ pyruvate was nearly twice the rate for $\left[3-{ }^{14} \mathrm{C}\right]$ pyruvate.

The activities of certain hepatic enzymes are presented in Table 6. The activities of ASPT and ICD were increased by an increase in the dietary crude protein level but not in the lysine level. In contrast, ME activity was decreased by an increase in the crude protein, but not the lysine level. 
Table 6. Effect of dietary crude protein (nitrogen $\times 6 \cdot 25$ ) level and lysine supplementation on liver enzyme activities (one unit is that amount of enzyme resulting in the production of 1 umol oxidized or reduced $N A D(P) /$ min at $25^{\circ}$ ) in broiler chickens*

(Mean values for four pen means per dietary treatment are expressed as units/kg body-weight)

\begin{tabular}{|c|c|c|c|c|c|}
\hline & $\begin{array}{c}\text { Crude protein } \\
(\mathrm{g})\end{array}$ & $\begin{array}{l}\text { Lysine content } \\
\text { (g) }\end{array}$ & ASPT & ICD & $\mathrm{ME}$ \\
\hline & 150 & 8 & $1843^{\mathrm{a}}$ & $277^{\mathrm{a}}$ & $249^{a}$ \\
\hline & 154 & 12 & $1791^{\mathrm{a}}$ & $320^{\mathrm{ab}}$ & $264^{\mathrm{a}}$ \\
\hline & 200 & 12 & $2371^{\mathrm{b}}$ & $415^{b}$ & $177^{\mathrm{b}}$ \\
\hline & Pooled SEM & & 143 & 53 & 15 \\
\hline
\end{tabular}

ASPT, aspartate aminotransferase ( $E C$ 2.6.1.1); ICD (NADP), isocitrate dehydrogenase (NADP) (EC 1. I.1.42); ME, malic enzyme (EC 1.1.1.40).

a.b Values within a column with unlike superscript letters were significantly different $(P<0.05)$.

* Chickens ( 7 -d-old; average of $145 \mathrm{~g}$ ) were assigned to these dietary treatments : (1) control, $200 \mathrm{~g}$ protein and $12 \mathrm{~g}$ lysine $/ \mathrm{kg}$ diet, (2) $150 \mathrm{~g}$ protein and $8 \mathrm{~g}$ lysine $/ \mathrm{kg}$ diet or (3) $154 \mathrm{~g}$ protein and $12 \mathrm{~g}$ lysine/ $\mathrm{kg}$ diet for a 2I d experimental period. Chickens were then selected from each treatment to determine the effects of dietary treatments on intermediary metabolism.

\section{DISCUSSION}

There are many reports concerning the relationship between dietary energy and protein and subsequent effects on intermediary metabolism; few studies attempt to explain the basis of changes in the lean: fat ratio in the animal carcass and the energy:protein relationship in the diet. Generally, as the dietary crude protein intake increases, transamination of amino acids, in excess of those required for growth, increases the demand for 2-oxoglutarate provided by mitochondrial citrate. Clark et al. (1979) proposed that avian acetyl CoAcarboxylase ( $E C$ 6.4.1.2) was more sensitive than mammalian acetyl CoA-carboxylase to activation by citrate.

The formulation of hypotheses concerning the dual role of dietary energy and crude protein and lipogenesis has been hampered by the relatively simple approach taken in the past when diets were formulated. In most cases, the level of crude protein was increased at the expense of dietary carbohydrate. We have examined the role of dietary crude protein $(120-300 \mathrm{~g} / \mathrm{kg})$ in conjunction with diets that contain the same quantity of carbohydrate (Rosebrough \& Steele, 1985b, 1986a; Rosebrough et al. 1988) and have found specific effects of both dietary protein and carbohydrate levels in the regulation of intermediary metabolism in the broiler. For example, a diet containing $230 \mathrm{~g}$ crude protein and $700 \mathrm{~g}$ carbohydrate equivalents $/ \mathrm{kg}$ will evoke a greater rate of lipogenesis than will a diet containing $230 \mathrm{~g}$ crude protein and $550 \mathrm{~g}$ carbohydrate equivalents $/ \mathrm{kg}$.

A logical progression in the study of the role of protein per se in the regulation of metabolism involves further experiments concerning protein quality (amino acid composition). The present study applies the concept of lysine as a limiting factor in protein quality. The results of the present study concerning metabolism in chickens fed on diets containing a marginal crude protein level complement our work (Rosebrough et al. 1982) in feeding similar regimens to turkey poults. In contrast, the turkey poult will eat a greater quantity of a lysine-supplemented diet relative to a control diet than will a chicken. Thus, comparing results between these two species may be difficult because of differences in voluntary feed intake.

The use of either pyruvate or acetate as substrates for lipogenesis permitted us to compare substrate utilization rates in broiler chickens. Pyruvate utilization always exceeded that of acetate. This finding suggests either divergent pathways for mitochondrial 
translocation or that both may use a common transport system that differs in its affinity for metabolites. As the dietary crude protein content was increased, the ratio $\left[3-{ }^{14} \mathrm{C}\right]-:[2-$ ${ }^{14} \mathrm{Clpyruvate}$ appearing in glucose also increased. This finding is not surprising as there is substantial glucose-C recycling in liver. It is of particular interest to compare the effects of lysine supplementation on liver glucose metabolism. Explants from supplemented chickens produced more glucose in the presence of pyruvate than did those from unsupplemented chickens. In contrast, use of pyruvate per se as a glucose precursor was not changed by an increase in dietary lysine. The formation of glucose from pyruvate requires partial metabolism through the Krebs' cycle, involving oxidation and subsequent loss of $\mathrm{C}$ atoms as well as randomization of product labelling in the formation of fumarate before anaplerotic reactions resulting in glucose synthesis. An examination of $\mathrm{C}$ metabolism would, therefore, allow a determination of $\mathrm{C}$ recycling during metabolism. For example, a ratio other than one indicates that radiolabelled glucose may have been formed through indirect pathways rather than a more direct route through pyruvate carboxylation. In contrast, hepatic fatty acid labelling ratios are not different from unity, which supports the hypothesis that pyruvate competes with acetate for mitochondrial transport. Once transported, the remaining $\mathrm{C}$ fragments are metabolized through citrate in a similar fashion to acetate.

In summary, it can be shown that a diet containing a marginal level of crude protein (150 $\mathrm{g} / \mathrm{kg}$ ) can be supplemented with lysine to give a growth rate similar to that attained with a diet containing a higher level of crude protein $(200 \mathrm{~g} / \mathrm{kg})$. Changes in intermediary metabolism such as oxidation, lipogenesis and liver glucose production are not equal, however, under these conditions. It is interesting to note the relationship between protein quality and the activities of ICD and ME. Both enzymes catalyse reactions that generate NADPH required for de novo lipogenesis and would seem to be 'lipogenic' in nature. Attention to the role of ME in NADPH production is important because the bird cannot produce NADPH through the pentose cycle and must rely on the reaction catalysed by ME to provide NADPH for de novo lipogenesis (Raheja et al. 1971). The product of the reaction catalysed by ICD, 2-oxoglutarate resulting from citrate via isocitrate, may be important because avian acetyl $\mathrm{CoA}$ carboxylase is distinctively sensitive to citrate concentrations, as mentioned previously. Citrate may be depleted by demand for 2-oxoglutarate provided through ICD. The same trend was noted for ASPT which is considered a key enzyme in protein metabolism and requires 2-oxoglutarate as an amine receptor. Also, if protein furnishes acetyl $\mathrm{CoA}$, the cytoplasmic reducing equivalents normally produced from dietary carbohydrate through aerobic glycolysis may be limiting because glucose production from dietary protein places a demand on limited supplies of these reducing equivalents. In the end, it must be stated that modifications in metabolism resulting from changes in the energy: protein ratio cannot be explained on the basis of meeting the need for a single limiting dietary amino acid.

Mention of a trade name, proprietary product or vendor does not constitute a guarantee or warranty of the product by USDA or imply its approval to the exclusion of other suitable products or vendors.

\section{REFERENCES}

Bartov, I. (1979). Nutritional factors affecting quantity and quality of carcass fat in chickens. Federation Proceedings 38, 2627-2639.

Cleland, W. W., Thompson, V. M. \& Barden, R. E. (1969). Isocitrate dehydrogenase (TPN specific) from pig heart. In Methods in Enzymology, vol. 13, pp. 30-33 [J. M. Lowenstein, editor]. New York: Academic Press.

Clark, S. D., Watkins, P. A. \& Lane, M. D. (1979). Acute control of fatty acid synthesis by cyclic AMP in the chick liver cell: possible site of inhibition of citrate formation. Journal of Lipid Research 20, 974-985. 
Donaldson, W. E. (1985). Lipogenesis and body fat in chicks: effects of calorie:protein ratios and dietary fat. Poultry Science 64, 1199-1204.

Donaldson, W. E., Combs, G. F. \& Romoser, G. L. (1956). Studies on energy levels in poultry rations. 1. The effect of calorie-protein of the ration on growth, nutrient utilization and body composition of chicks. Poultry Science 35, 1100-1204.

Folch, J., Lees, M. \& Sloane-Stanley, G. H. (1957). A simple method for the isolation and purification of total lipids from animal tissues. Journal of Biological Chemistry 226, 497-509.

Hanks, J. H. \& Wallace, R. E. (1949). Relation of oxygen and temperature in the preservation of tissues by refrigeration. Proceedings of the Society of Experimental Biology and Medicine 71, 196-200.

Hsu, R. Y. \& Lardy, H. A. (1969). Malic enzyme. In Methods in Enzymology, vol. 13, pp. 230-235 [J. M. Lowenstein, editor]. New York: Academic Press.

Kirk, R. E. (1968). Experimental Design Procedures for the Behavioral Sciences. Belmont, California: Wadsworth Publishing Company,

Martin, R. J. \& Herbein, J. H. (1976). A comparison of the enzyme levels and in vitro utilization of various substrates for lipogenesis in pair-fed lean and obese pigs. Proceedings of the Society for Experimental Biology and Medicine 151, 231-235.

National Research Council (1984). Nutrient Requirements of Poultry. Washington, DC: National Academy Press.

Raheja, K. K., Snedecor, J. G. \& Freedland, R. A. (1971). Activities of some enzymes involved in lipogenesis, gluconeogenesis, glycolysis, and glycogen metabolism in chicks from day of hatch to adulthood. Comparative Biochemistry and Physiology 39B, 237-249.

Rosebrough, R. W., McMurtry, J. P., Mitchell, A. D. \& Steele, N. C. (1988). Protein and energy restrictions in the broiler chicken. 6. Effect of dietary protein and energy restrictions on carbohydrate and lipid metabolism and metabolic hormone profiles. Comparative Biochemistry and Physiology 90, 311-316.

Rosebrough, R. W., McMurtry, J.P. \& Steele, N.C. (1987). Protein and energy relations in the broiler. 5, Lipogenesis, glucose production and metabolic hormone levels as functions of age and dietary protein levels. Growth 51, 309-320.

Rosebrough, R. W. \& Steele, N. C. (1985a). Energy and protein relations in the broiler. I. Effect of protein levels and feeding regimes on growth, body composition, and in vitro lipogenesis of broiler chicks. Poultry Science 64, $119-126$.

Rosebrough, R. W. \& Steele, N. C. (1985b). Protein and energy relations in the broiler. 2. Effect of varied protein and constant carbohydrate levels on body composition and lipid metabolism. Growth 49, 479-489.

Rosebrough, R. W. \& Steele, N. C. (1986a). Protein and energy relations in the broiler. 3. Growth and in vitro metabolism in male and female chickens used as parent stock. Growth 50, 63-75.

Rosebrough, R. W. \& Steele, N. C. $(1986 b)$. Energy and protein relations in the broiler. 4. Role of sex, line, and substrate on in vitro lipogenesis. Growth 50, 461-471.

Rosebrough, R.W. \& Steele, N., C. (1987). Methods to assess glucose and lipid metabolism in avian liver explants. Comparative Biochemistry and Physiology 88B, 1041-1049.

Rosebrough, R. W., Steele, N. C. \& Frobish, L. T. (1982). Studies on the role of lysine and protein in the regulation of lipogenesis by the turkey poult. Poultry Science 61, 2056-2059.

Thomas, O. P. \& Combs, G. F. (1967). Relationship between serum protein level and body composition in the chick. Journal of Nutrition 91, 468-472.

Yeh, Y. Y. \& Leveille, G. A. (1969). Effect of dietary protein on hepatic lipogenesis in the growing chick. Journal of Nutrition 98, 356-366. 